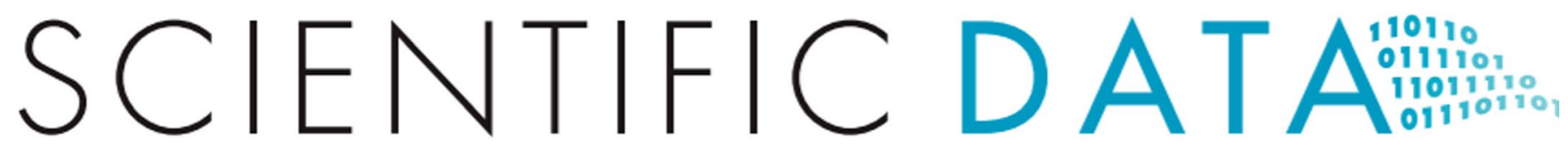

Check for updates

OPEN

Published online: 26 February 2021

\title{
Author Correction: Transcriptome and translatome profiles of Streptomyces species in different growth phases
}

\section{Woori Kim, Soonkyu Hwang, Namil Lee, Yongjae Lee, Suhyung Cho, Bernhard Palsson (D) \& Byung-Kwan Cho}

Correction to: Scientific Data https://doi.org/10.1038/s41597-020-0476-9, published online 08 May 2020

Following publication, it was found that two accession numbers given in the manuscript text were incorrect. A figure label was also missing from Figure $3 \mathrm{f}$.

Both the HTML and PDF versions have been updated to reflect these changes.

(i) Open Access This article is licensed under a Creative Commons Attribution 4.0 International License, which permits use, sharing, adaptation, distribution and reproduction in any medium or format, as long as you give appropriate credit to the original author(s) and the source, provide a link to the Creative Commons license, and indicate if changes were made. The images or other third party material in this article are included in the article's Creative Commons license, unless indicated otherwise in a credit line to the material. If material is not included in the article's Creative Commons license and your intended use is not permitted by statutory regulation or exceeds the permitted use, you will need to obtain permission directly from the copyright holder. To view a copy of this license, visit http://creativecommons.org/licenses/by/4.0/.

(C) The Author(s) 2021 